\title{
Human Natural Killer Cells Produce Abundant Macrophage Inflammatory Protein-1 $\alpha$ in Response to Monocyte-derived Cytokines
}

\author{
Eric M. Bluman, ${ }^{\star}$ Kevin J. Bartynski, ${ }^{\ddagger}$ Belinda R. Avalos, ${ }^{\ddagger}{ }^{\ddagger}$ and Michael A. Caligiuri ${ }^{\star}$ \\ *Division of Medicine, Departments of Hematologic Oncology and Bone Marrow Transplantation, Molecular Medicine, and Molecular \\ Immunology, Roswell Park Cancer Institute, Buffalo, New York 14263; and ${ }^{\ddagger}$ Department of Internal Medicine, ${ }^{\S}$ Divisions of Bone \\ Marrow Transplantation, Hematology and Oncology, The Ohio State University Hospitals, Columbus, Ohio 43210
}

\begin{abstract}
Once infected by obligate intracellular pathogens, monocytes/macrophages release cytokines that activate natural killer (NK) cells. NK cells in turn produce and secrete monocyte/macrophage activating factors such as interferongamma (IFN- $\gamma$ ), which are important in the early control of these infections. Here we demonstrate that human NK cells are potent producers of another monocyte/macrophage-activating factor, macrophage inflammatory protein-1 $\alpha$ (MIP$1 \alpha)$. Fresh NK cells produce negligible amounts of MIP-1 $\alpha$ after stimulation with the monocyte-derived cytokines IL12, TNF- $\alpha$, IL-1 $\beta$, or IL-10, while stimulation with IL-15 alone results in modest MIP- $1 \alpha$ production. Abundant NK cell production of MIP-1 $\alpha$ is seen after costimulation with IL-12 and IL-15, and is dose-dependent. Combinations of IL-12 with TNF- $\alpha$, IL-1 $\beta$, or IL-10 are substantially less effective inducers of MIP-1 $\alpha$ production by NK cells. NK cell $M I P-1 \alpha$ mRNA transcripts were detectable within $1 \mathrm{~h}$ after costimulation with IL-12 plus IL-15 and steadily increased over $24 \mathrm{~h}$, with a concomitant increase in protein production detectable at $\mathbf{1 2} \mathrm{h}$. Resting NK cells constitutively express mRNA transcript for a MIP- $1 \alpha$ receptor, and costimulation with IL-12 and IL-15 upregulates its level of expression. Equilibrium binding studies with radioiodinated MIP-1 $\alpha$ were consistent with the induction of a single class of high affinity MIP-1 $\alpha$ receptors on NK cells costimulated with IL12 and IL-15. Addition of exogenous MIP-1 $\alpha$ to resting NK cells did not enhance cytokine production, but did increase NK cytotoxic activity. The requirement for IL-15 as a critical cofactor for NK cell production of MIP-1 $\alpha$ suggests a potentially unique role for this monocyte-derived cytokine in combination with IL-12. As MIP-1 $\alpha$ is known to potentiate the actions of IFN- $\gamma$ on monocytes and to suppress human immunodeficiency virus replication, the NK cell's production of MIP-1 $\alpha$ may be important during the innate immune response to infection. (J. Clin. Invest. 1996. 97: 2722-2727.) Key words: chemokine - innate immunity • IL-15 • IL-12 • monokine
\end{abstract}

Address correspondence to Michael A. Caligiuri, M.D., Roswell Park Cancer Institute, Buffalo, New York 14263-0001. Phone: 716-8453087; FAX: 716-845-2343; E-mail: caligiuri@dm3100.med.buffalo.edu Received for publication 21 January 1996 and accepted in revised form 27 March 1996.

J. Clin. Invest.

(c) The American Society for Clinical Investigation, Inc. 0021-9738/96/06/2722/06 \$2.00

Volume 97, Number 12, June 1996, 2722-2727

\section{Introduction}

Natural killer $(\mathrm{NK})^{1}$ cells are innate immune effector cells thought to be important during the early stages of infection. Monocytes infected with obligate intracellular pathogens such as Listeria monocytogenes, Toxoplasma gondii, and Leishmania major release cytokines which in turn activate NK cells to secrete interferon gamma (IFN- $\gamma$ ), tumor necrosis factor-alpha (TNF- $\alpha$ ), and granulocyte-macrophage colony stimulating factor (GM-CSF) in a positive feedback loop. Indeed, a number of experimental immunodeficient animal models have clearly demonstrated the importance of NK cell IFN- $\gamma$ production in preventing overwhelming infection from several obligate intracellular pathogens (reviewed in references 1 and 2). Additionally, NK cell production of both IFN- $\gamma$ and TNF- $\alpha$ appears to play a role in the pathogenesis of septic shock $(3,4)$. The number of NK-derived monocyte-activating factors that may contribute to protection from microbial invasion and/or septic shock is currently unknown.

Macrophage inflammatory protein- $1 \alpha(\mathrm{MIP}-1 \alpha)$ is a member of the chemokine superfamily of low molecular mass secretory proteins with phagocyte-stimulating and proinflammatory properties. MIP-1 $\alpha$ has been shown to potentiate monocyte/macrophage activation induced by IFN- $\gamma$ (5) and most recently, to suppress replication by the human immunodeficiency virus (HIV) (6). Here we provide the first evidence that human NK cells produce MIP-1 $\alpha$ after costimulation with a specific combination of monocyte-derived cytokines. Further, we characterize MIP- $1 \alpha$ production, receptor expression and binding, as well as the consequences of its binding on human NK cell function.

\section{Methods}

Isolation of $\mathrm{CD}^{-} \mathrm{CD}^{-} 6^{+}$human cells and cell lines. Human NK cells were isolated from fresh blood to $\geq 97 \%$ purity using immunomagnetic bead depletion followed by sorting for $\mathrm{CD} 56^{+} \mathrm{NK}$ cells or CD56 ${ }^{\text {bright }}$ NK cells on a FACstar Plus ${ }^{\circledR}$ (Becton Dickinson, San Jose, CA) as previously described (7). The COLO 205 cell line was obtained from the ATCC (Rockville, MD) and the NK-92 cell line was a generous gift of Dr. H.-G. Klingemann (8).

Cytokines, NK cytokine production, and monoclonal antibodies (mAbs). Recombinant human (rh) IL-15 was provided by Immunex Corp. (Seattle, WA). rhIL-12 (sp act $4.5 \times 10^{6} \mathrm{U} / \mathrm{mg}$ ) was provided by Genetics Institute (Cambridge, MA). rhIL-10 (sp act $11.0 \times 10^{6}$ IRU/mg) was provided by Schering-Plough (Kenilworth, NJ). rhTGF- $\beta_{2}$ (TGF- $\beta$ ) was a generous gift of Dr. Thomas B. Tomasi

1. Abbreviations used in this paper: MIP, macrophage inflammatory protein; NK, natural killer. 
(Roswell Park Cancer Institute, Buffalo, NY). rhTNF- $\alpha$ was provided by Asahi Brewing Co. (Tokyo, Japan, sp act $2 \times 10^{3} \mathrm{U} / \mathrm{mg}$ ) and rhIL$1 \beta$ was purchased from Pharmacia Biotech. Inc. (Piscataway, NJ). rhMIP-1 $\alpha$ was purchased from Biosource International (Carmalito, CA). rhIL-2 (sp act $1.53 \times 10^{7} \mathrm{IU} / \mathrm{mg}$ ) was provided by Hoffmann-La Roche (Nutley, NJ). All cytokines used in this study were diluted to working concentrations in $0.1 \%$ human albumin (Armor Pharmaceuticals, Kankakee, IL) in RPMI 1640 (Sigma Diagnostics, St. Louis, $\mathrm{MO}$ ). Anti-CD25 (anti-IL-2R $\alpha$ ) and non-reactive isotype control $\mathrm{mAbs}$ were purchased from Biosource International.

For all assays of NK cell cytokine production, $2 \times 10^{4}$ purified $(\geq$ 97\%) fresh human NK cells were plated in 96-round bottom wells containing $250 \mu \mathrm{l}$ of RPMI 1640 medium (Sigma Chemical Co., St. Louis, MO) supplemented with $10 \%$ human AB serum (C-Six Diagnostics, Mequon, WI), antibiotics, and various amounts of rh cytokines as indicated. Cultures were incubated for $72 \mathrm{~h}$ at $37^{\circ} \mathrm{C}$ unless otherwise indicated, at which time $200 \mu \mathrm{l}$ of supernatant was removed for measurement of MIP- $1 \alpha$ production without disturbing the cell pellet. Measurement of human MIP- $1 \alpha$ production was performed by ELISA (sensitivity: $2.0 \mathrm{pg} / \mathrm{ml}, \mathrm{R} \&$ D Systems, Minneapolis, MN) following the manufacturer's instructions.

Analysis of RNA. $2.0 \times 10^{7} \mathrm{NK}$ cells $\left(\geq 85 \% \mathrm{CD}^{-} \mathrm{CD}^{-} 6^{+}\right)$were isolated from fresh leukopacs using immunomagnetic bead depletion and either placed immediately in RNAzol (Biotecx Laboratories, Friendswood, TX), or incubated with IL-12 (10 U/ml) and/or IL-15
$(10 \mathrm{ng} / \mathrm{ml})$ at $37^{\circ} \mathrm{C}$ for indicated times, followed by lysis in RNAzol. Total RNA was extracted according to the manufacturer's recommendation, and Northern blot analysis was performed as previously described (9). The GOS19.1 cDNA (a generous gift of Dr. D.R. Forsdyke, Queens University, Hamilton, Ontario), is the full length $1 \mathrm{~kb}$ cDNA encoding the human MIP-1 $\alpha$ protein (10). The C-C CKR-1 cDNA (a generous gift of Dr. T. Schall, DNAX Research Institute, Palo Alto, CA) is a $1 \mathrm{~kb}$ cDNA encoding a known protein receptor for MIP-1 $\alpha$ (11). Both probes were labeled with the Prime It ${ }^{\circledR}$ II random primer labeling kit (Stratagene Inc., LaJolla, CA) as per the manufacturers instructions, prior to hybridization.

${ }^{125} I-M I P-1 \alpha$ binding and unlabeled ligand competition. NK cells $\left(\geq 85 \% \mathrm{CD}^{-} \mathrm{CD}^{-} 6^{+}\right)$were isolated from fresh leukopacs using immunomagnetic bead depletion, and incubated in medium alone or medium with IL-15 $(10 \mathrm{ng} / \mathrm{ml})$ and IL-12 $(10 \mathrm{U} / \mathrm{ml})$ for $8 \mathrm{~h}$, followed by overnight shipment at room temperature under otherwise identical culture conditions. Upon receipt, NK cells were first checked for viability by trypan blue ( $\geq 90 \%$ ), and tested for specific binding to radiolabeled ${ }^{125}$ I-MIP- $1 \alpha$ as described (12). Briefly, the NK cells were washed twice with PBS ( $\mathrm{pH} 7.4$ ) and resuspended at $2.0 \times 10^{6} \mathrm{cells} / \mathrm{ml}$ in binding buffer consisting of Iscove's modified Dulbecco's medium (IMDM) containing $25 \mathrm{mmol} / \mathrm{liter}$ Hepes and $4 \mathrm{mg} / \mathrm{ml} \mathrm{BSA} \mathrm{(pH} \mathrm{7.4).}$ The cells were incubated for $1 \mathrm{~h}$ at $23^{\circ} \mathrm{C}$ with varying concentrations of ${ }^{125} \mathrm{I}$-MIP- $1 \alpha$, ranging from 0.01 to $2 \mathrm{nmol} / \mathrm{liter}$, in the presence or absence of a 100-fold excess of unlabeled MIP-1 $\alpha$ in a final volume of
A

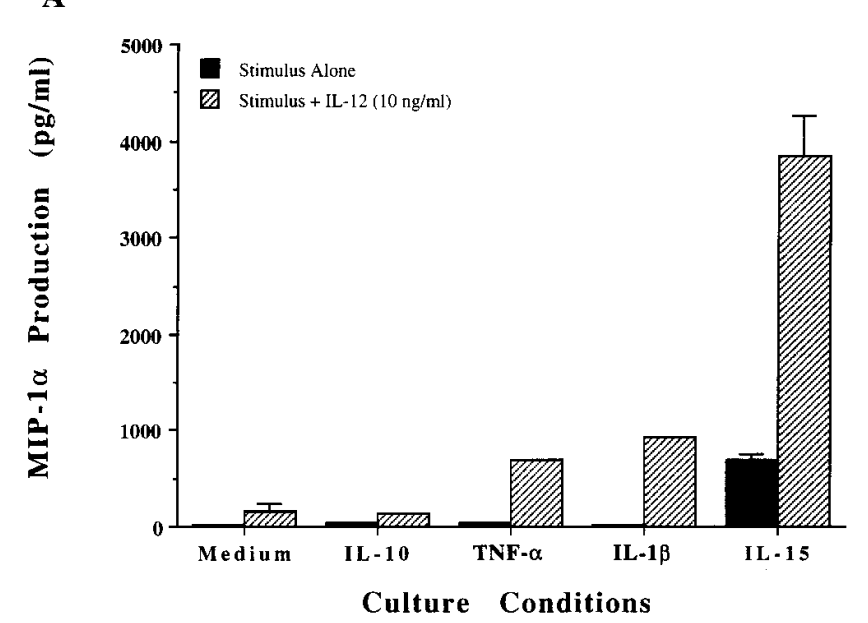

C

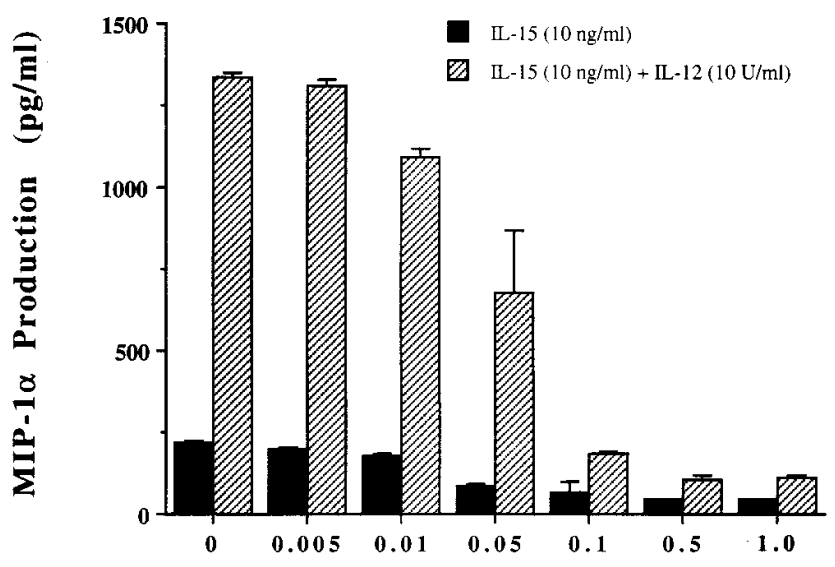

Concentration of TGF- $\beta$ (ng/ml)
B

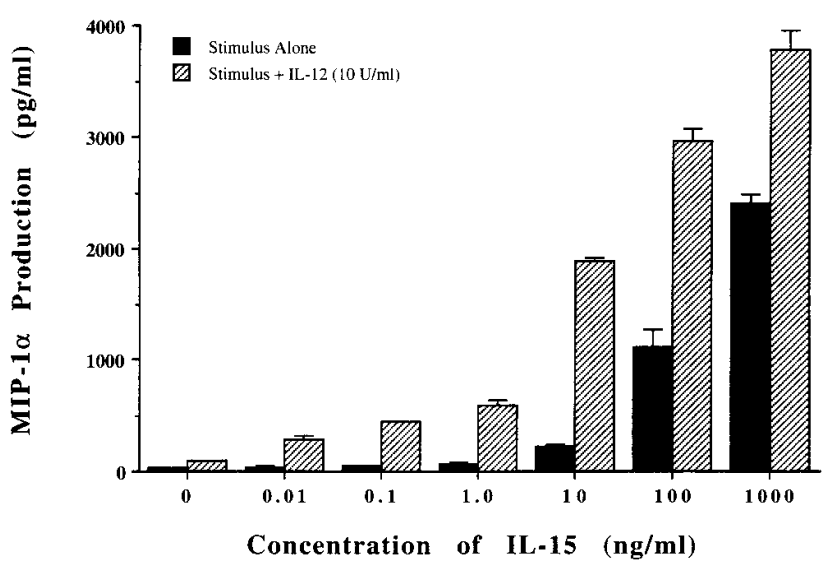

Figure 1. NK cell production of MIP-1 $\alpha$ in response to monocytederived cytokines. Human NK cells ( $\geq 97 \%$ ) were plated at $2 \times 10^{4}$ cells per well in medium containing various rh cytokines. After $72 \mathrm{~h}$ of culture, supernatants were harvested and analyzed for MIP- $1 \alpha$ protein by ELISA. Values represent mean $\pm \mathrm{SE}$ and are representative of three independent experiments. $(A)$ MIP- $1 \alpha$ production by CD56 ${ }^{+}$cells cultured with IL-10 $(50 \mathrm{ng} / \mathrm{ml}) ; \mathrm{TNF}-\alpha(2000 \mathrm{U} / \mathrm{ml}) ; \mathrm{IL}-$ $1 \beta(100 \mathrm{ng} / \mathrm{ml}) ; \mathrm{IL}-15(100 \mathrm{ng} / \mathrm{ml})$ in the presence or absence of IL-12 $(10 \mathrm{U} / \mathrm{ml})$. (B) NK cell MIP-1 $\alpha$ production in response to increasing concentrations of IL-15, in the presence and absence of IL-12. $(C)$ The suppressive effect of TGF- $\beta$ on MIP- $1 \alpha$ production by $\mathrm{CD} 56^{+}$ NK cells is dose dependent. Increasing concentrations of TGF- $\beta$ were

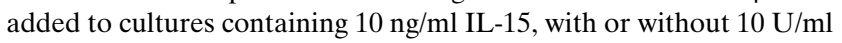
IL-12. 
A

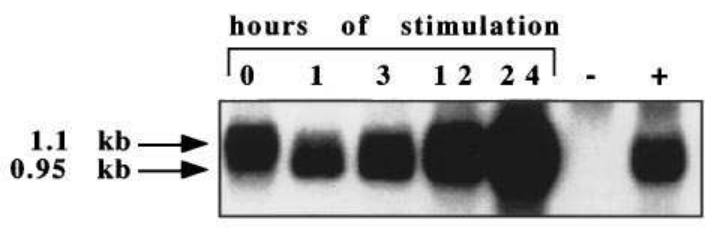

$18 \mathrm{~s}$

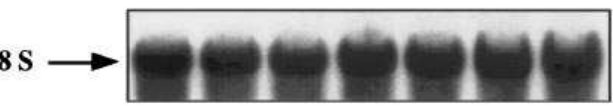

B

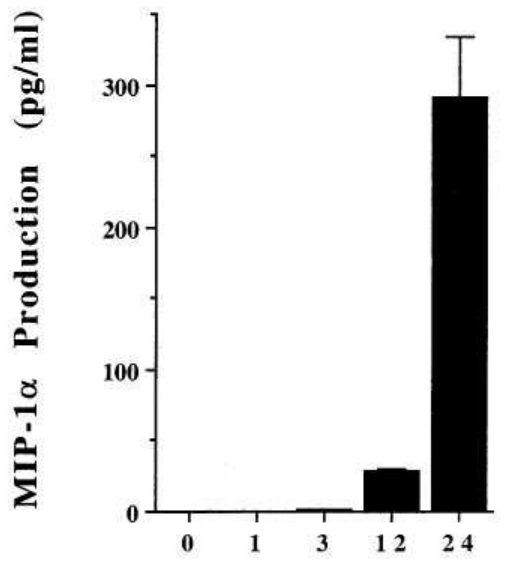

Hours of Stimulation

Figure 2. Kinetics of $M I P-1 \alpha$ gene expression in human NK cells after costimulation with IL-12 and IL-15. Freshly isolated ( $\geq 85 \%)$ NK cells were cultured in the presence of IL-12 and IL-15 for the indicated lengths of time. Cells were processed for total RNA and supernatants were collected for protein measurements. $(A)$ Representative Northern analysis for the induction of MIP- $1 \alpha$ gene expression over time. Resting NK cells expressed a 1.1-kb transcript previously only seen in cycloheximide-treated $\mathrm{T}$ cells, while the $0.95-\mathrm{kb}$ transcript typically identified by the GOS19.1 probe is absent. After costimulation with IL-12 (10 U/ml) and IL-15 $(10 \mathrm{ng} / \mathrm{ml})$, the $0.95-\mathrm{kb}$ transcript appears at $1 \mathrm{~h}$ and steadily increases, while the $1.1-\mathrm{kb}$ transcript is absent at $1 \mathrm{~h}$ and then increases thereafter. ( -$)$ RNA from the COLO 205 cell line; $(+)$ RNA from the NK-92 cell line stimulated for $3 \mathrm{~h}$ with IL-12 and IL-15. Autoradiographs were exposed to blots for $20 \mathrm{~h}$. The same blot was reprobed for $18 \mathrm{~S}$ rRNA (18 S) to confirm equal loading of each lane. $(B)$ MIP-1 $\alpha$ protein production of NK cells over time. $2 \times 10^{4} \mathrm{NK}$ cells isolated from the same source as those in $A$ were plated into a 96-well plate with IL-12 and IL-15. Their supernatants were assayed for MIP- $1 \alpha$ production by ELISA at the indicated times.

$400 \mu$ l. After incubation, $0.75 \mathrm{ml}$ of an ice-cold mixture of $75 \%$ FBS in binding buffer was added to the cells, the tubes were vortexed, and the cells were pelleted by centrifugation. The supernatant fluids were aspirated and the radioactivity contained in the cell pellets was measured in a gamma counter. All binding experiments were performed in duplicate. Specific binding was defined as the amount of binding competed by a 100 -fold excess of unlabeled MIP- $1 \alpha$. Equilibrium binding data were analyzed according to the method of Scatchard (13) and by weighted nonlinear least-squares curve fitting as described by Munson and Rodbard using the LIGAND program (14). Objective statistical criteria (F test, extra sum squares principle) were used to evaluate the goodness of fit and for discriminating between receptor binding models.

NK cell cytotoxicity assay. Purified ( $\geq 97 \%$ ) NK cells were cultured overnight in V-bottom 96-well plates with indicated concentrations of MIP-1 $\alpha$. After overnight incubation at $37^{\circ} \mathrm{C},{ }^{51} \mathrm{Cr}$-labeled NK-resistant COLO 205 target cells were added to each well to give effector: target of 2.5. After a 4-h incubation, supernatants were harvested and specific cell lysis was calculated as previously described (15).

\section{Results}

Costimulation of NK cells with specific monocyte-derived factors induces MIP-1 $\alpha$ production by NK cells. In an effort to determine which, if any, monocyte-derived cytokines would stimulate the production of MIP- $1 \alpha$ by NK cells, we treated purified $(\geq 97 \%) \mathrm{CD}^{+} 6^{+} \mathrm{NK}$ cells with several rh cytokines known to modulate the inflammatory response. Fig. 1 shows that culture of human NK cells in the presence of IL-10, IL-1 $\beta$, IL-12, or TNF- $\alpha$ did not stimulate significant production of MIP- $1 \alpha$, compared with that seen with medium alone. Culture of NK cells with $100 \mathrm{ng} / \mathrm{ml}$ IL-15 alone resulted in modest production of MIP- $1 \alpha(500 \mathrm{pg} / \mathrm{ml})$, comparable to the costimulation of NK cells with IL-12 and IL-1 $\beta$, or IL-12 and TNF- $\alpha$ (Fig. $1 A$ ). However the costimulation of NK cells with IL-12 and IL-15 had a clear synergistic effect. Under these conditions MIP- $1 \alpha$ concentrations were $3851 \pm 414 \mathrm{pg} / \mathrm{ml}$. In the presence of $10 \mathrm{U} /$ $\mathrm{ml}$ IL-12, a clear dose-response curve with IL-15 was noted. Significant MIP- $1 \alpha$ production first occurred at IL-15 concentrations of $10 \mathrm{ng} / \mathrm{ml}$ and continued to increase through concentrations of $1 \times 10^{3} \mathrm{ng} / \mathrm{ml}($ Fig. $1 \mathrm{~B}$ ). In contrast, the culture of NK cells with IL-15, IL-12, and TGF- $\beta$ resulted in a clear dosedependent inhibition of MIP- $1 \alpha$ production which was nearly complete at $0.5 \mathrm{ng} / \mathrm{ml}$ TGF- $\beta$ (Fig. 1 C). IL-10 had no inhibitory effect, and actually showed a modest, dose dependent, additive effect on NK cell MIP- $1 \alpha$ production when combined with IL-15 (not shown).

Kinetics of MIP-1 $\alpha$ gene expression. We assayed NK cell production of MIP- $1 \alpha$ mRNA transcript and protein over time. Results are shown in Fig. 2, $A$ and $B$. Interestingly, resting NK cells express a 1.1-kb transcript previously only seen in cycloheximide-treated $\mathrm{T}$ cells after PHA activation (16). The $0.95-\mathrm{kb}$ transcript normally identified with the full length GOS19.1 probe was absent in resting NK cells, but appeared after a $1 \mathrm{~h}$ costimulation with IL-12 and IL-15 (Fig. $2 A$ ). Expression of this smaller transcript increased over the $24 \mathrm{~h}$ of the assay. The 1.1-kb transcript initially diminished over the first hour of costimulation and then increased in parallel with the $0.95-\mathrm{kb}$ species. MIP- $1 \alpha$ protein was first detected in the supernatant of an identical culture at $12 \mathrm{~h}$ after costimulation and increased to approximately $300 \mathrm{pg} / \mathrm{ml}$ after $24 \mathrm{~h}$ (Fig. 2 B). Production continued to increase for several days afterward into the $\mathrm{ng} / \mathrm{ml}$ range (not shown). Importantly, the kinetics of MIP- $1 \alpha$ production are nearly identical to the kinetics of NK cell IFN- $\gamma$ production following the same costimulation (17).

$N K$ cell expression of C-C CKR-1 $\mathrm{mRNA}$ and ${ }^{125} I-M I P-1 \alpha$ binding affinity. We performed a Northern analysis on total RNA obtained from fresh NK cells and NK cells cultured for $24 \mathrm{~h}$ in IL-15, or IL-15 and IL-12, to assess for the MIP-1 $\alpha$ receptor gene product. Fig. $3 A$ shows that resting and IL-15-activated NK cells express similar amounts of $C-C$ CKR-1 transcript. Costimulation with IL-15 and IL-12 resulted in a substantial increase in gene expression. These results were confirmed by the reverse transcription polymerase chain reaction (data not shown). Receptor binding studies were also performed on untreated NK cells and those costimulated with IL12 and IL-15. Only low levels of specific binding of MIP-1 $\alpha$ could be detected on untreated NK cells (data not shown). Treatment of NK cells with a combination of IL-12 and IL-15 


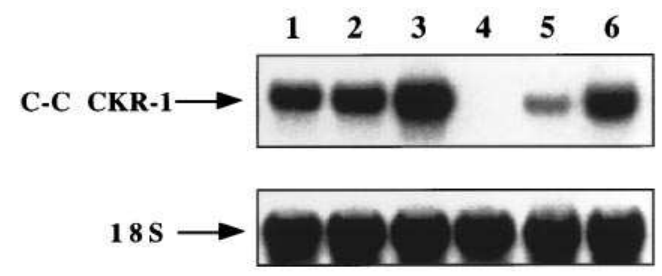

B

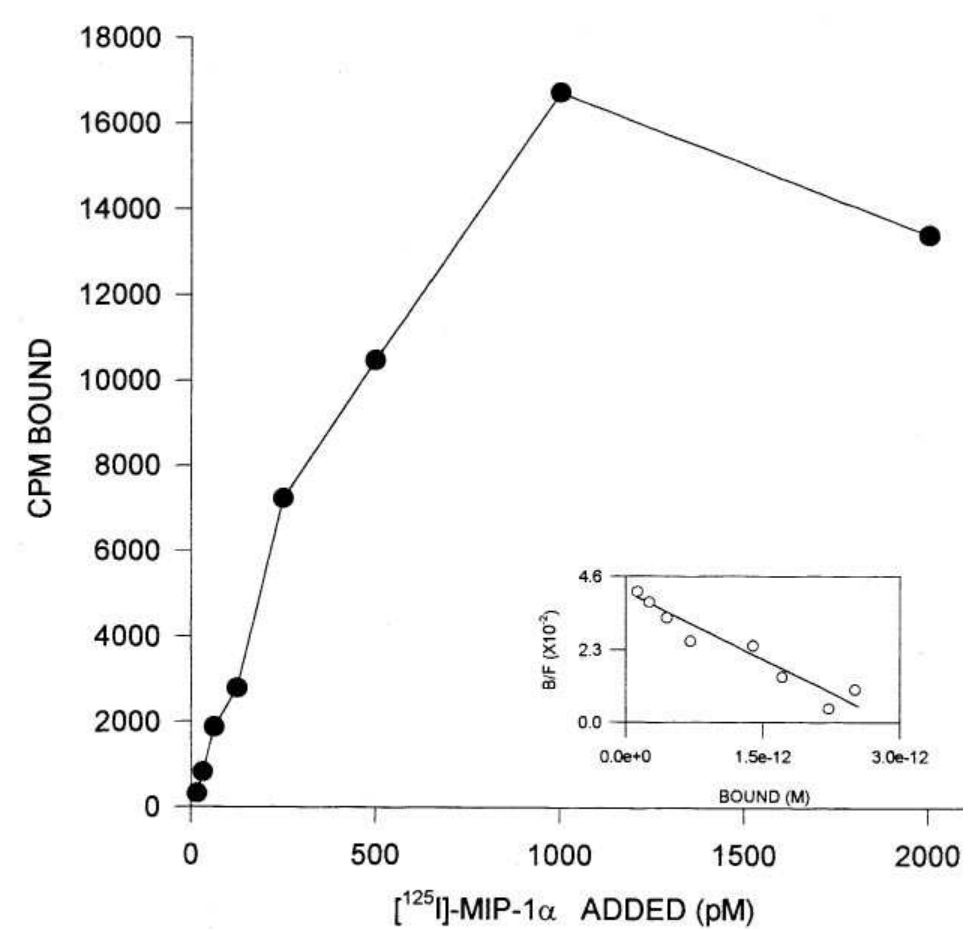

Figure 3. Characterization of MIP- $1 \alpha$ receptor expression on human NK cells. $(A)$ Human NK cells ( $\geq 85 \%$ ) were cultured at $5 \times 10^{5}$ cells/ml for $24 \mathrm{~h}$ under one of the following conditions: medium alone, medium and IL-15 (10 ng/ml), or medium, IL-15 (10 $\mathrm{ng} / \mathrm{ml})$ and IL-12 $(10 \mathrm{U} / \mathrm{ml})$. Total cellular RNA was isolated, prepared for Northern analysis and probed for $C$ - $C$ CKR-1 message. Lane 1, resting NK cells; lane 2, IL-15; lane 3, IL-15 plus IL-12; lane 4, COLO 205 (negative control); lane 5, LPS-activated monocytes (positive control); and lane 6 , resting monocytes (positive control). The same blot was reprobed for 18 $\mathrm{S}$ rRNA to confirm equal loading of lanes. Autoradiographs were exposed for $20 \mathrm{~h}$. (B), MIP-1 $\alpha$ receptor protein expression. Equilibrium binding curve and Scatchard plot (inset) are shown for NK cells following a $24 \mathrm{~h}$ incubation in medium containing IL-12 $(10 \mathrm{U} / \mathrm{ml})$ and IL-15 $(10 \mathrm{ng} / \mathrm{ml})$. CD56 ${ }^{+}$NK cells were incubated with varying concentrations of ${ }^{125} \mathrm{I}-\mathrm{MIP}-1 \alpha$ with or without a 100 -fold excess of unlabeled MIP$1 \alpha$ as described in Methods. The binding curves are plotted as CPMs bound versus total concentration of ${ }^{125} \mathrm{I}$-MIP- $1 \alpha$ added and illustrate the difference between total binding and nonspecific binding. The Scatchard analysis is plotted as the ratio of bound (B) to free $(\mathrm{F}){ }^{125}$ I-MIP-1 $\alpha$ versus the concentration of bound ${ }^{125}$ I-MIP- $1 \alpha$. Results are representative of two independent experiments.

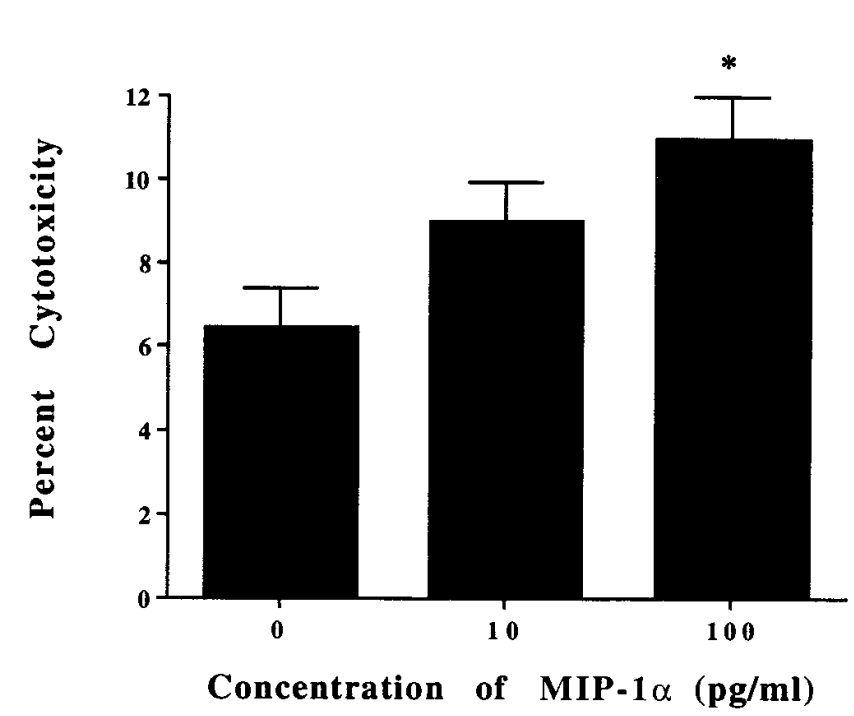

Figure 4. Exogenous MIP-1 $\alpha$ enhances NK cell cytotoxicity. NK cells ( $\geq 97 \%$ ) were first incubated overnight in medium containing varying concentrations of MIP- $1 \alpha$. Standard 4 h cytotoxicity assays were resulted in the induction of a single class of high affinity receptors for MIP- $1 \alpha$ with a $K_{\mathrm{d}}$ of $69-95 \mathrm{pM}$ and an expression density of 125-173 sites per cell (Fig. $3 B$ ).

Functional response of human NK cells to MIP-1 $\alpha$ receptor activation. Despite the fact that NK cells produced MIP-1 $\alpha$ and expressed receptors for MIP- $1 \alpha$, the chemokine itself had no effect on augmenting NK cell production of IFN- $\gamma$, TNF- $\alpha$, or GM-CSF (not shown). However, low concentrations of rhMIP- $1 \alpha$ did enhance NK cell cytotoxic activity against NKresistant tumor target cells in the absence of other cytokines (Fig. 4), and in the presence of IL-15 (not shown).

Induction of MIP-1 $\alpha$ production by $I L-15$ versus $I L-2$. IL-15 activates human NK cells through the intermediate affinity IL-2 receptor (IL-2R $\beta \gamma$ ), but does not utilize the alpha $(\alpha)$ subunit of the high affinity IL-2 receptor (IL-2R $\alpha \beta \gamma$ ). IL-2 can activate NK cells through IL-2R $\beta \gamma$ and IL-2R $\alpha \beta \gamma$ (15). The CD56 ${ }^{\text {bright }} \mathrm{NK}$ cell subset constitutively expresses both the in-

then conducted using the NK-resistant COLO 205 cell line as targets. Results represent the mean percent cytotoxicity for indicated conditions of triplicate wells. The results are representative of three independent experiments. $* P \leq 0.025$. 


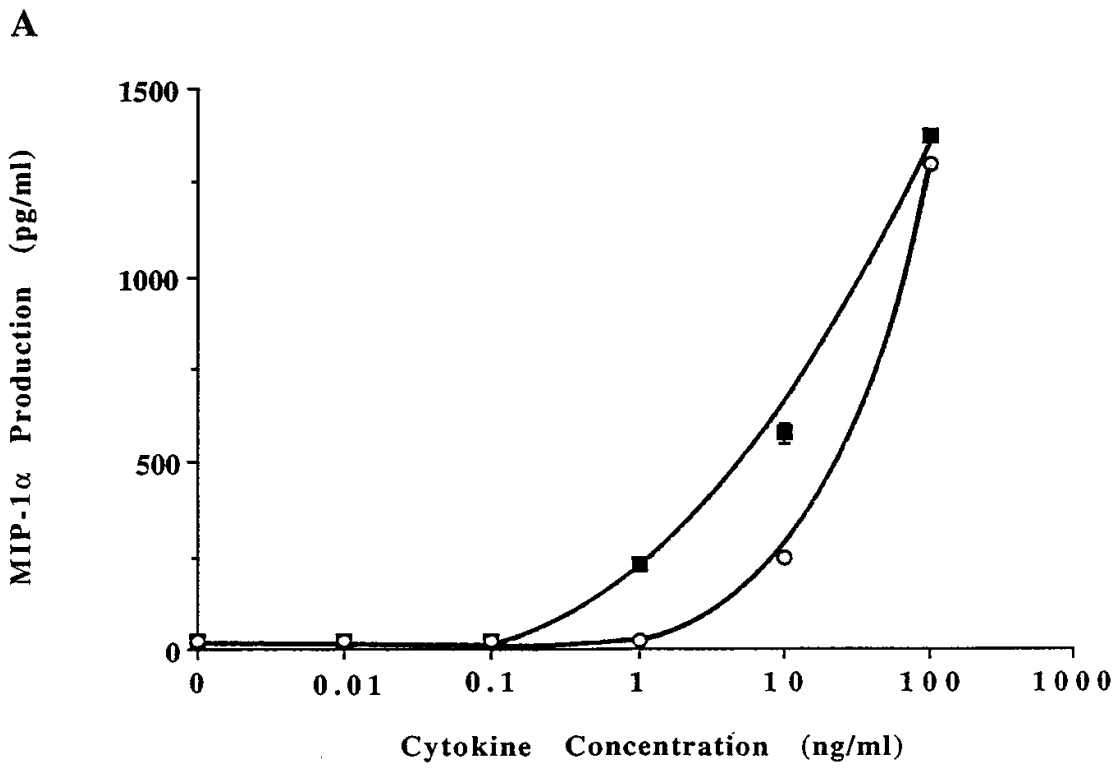

B

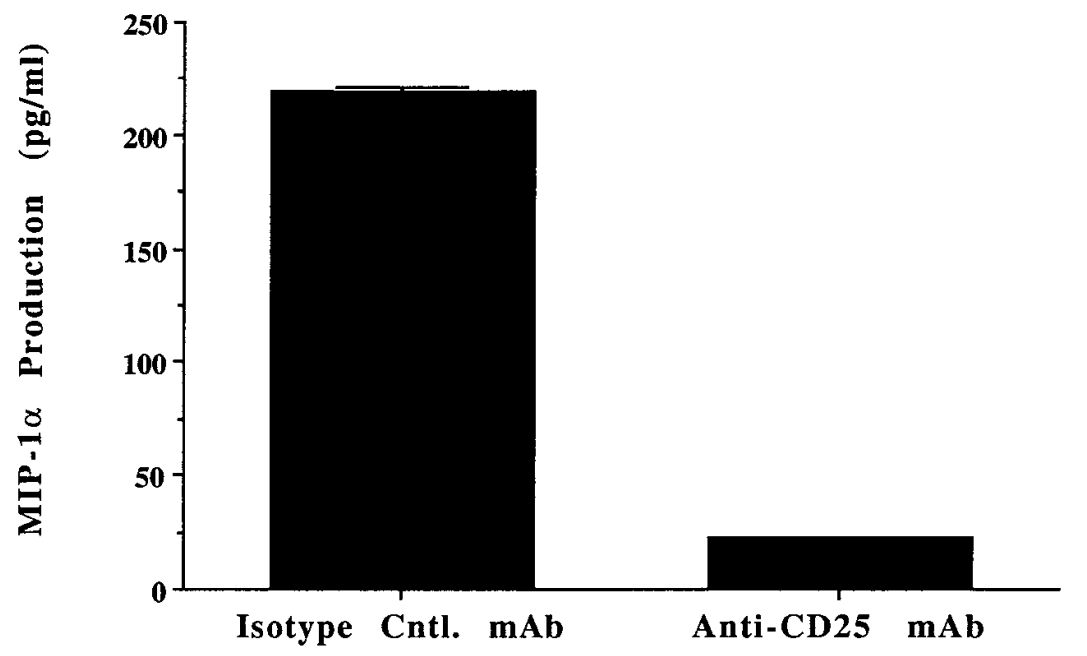

Figure 5. CD56 bright NK cell production of MIP$1 \alpha$ in response to IL-2 versus IL-15. (A) Human CD56 $6^{\text {bright }} \mathrm{NK}$ cells $(\geq 97 \%)$ were plated at $2 \times$ $10^{4}$ cells per well in medium containing increasing concentrations of either IL-2 ( $\mathbf{\square})$ or IL-15 (O). After $72 \mathrm{~h}$ of culture, supernatants were harvested and analyzed for MIP- $1 \alpha$ protein by ELISA. Values represent mean \pm SE of triplicate wells and are representative of three independent experiments. $(B)$ Human CD56 bright NK cells $(\geq 97 \%)$ were plated at $2 \times 10^{4}$ cells per well in medium containing $1 \mathrm{ng} / \mathrm{ml} \mathrm{IL-2}$ with an isotype control $\mathrm{mAb}$ or $1 \mathrm{ng} / \mathrm{ml} \mathrm{IL}-2$ with an anti-CD25 (anti-IL-2R $\alpha) \mathrm{mAb}$. After $72 \mathrm{~h}$ of culture, supernatants were harvested and assayed for MIP- $1 \alpha$ protein by ELISA. Values represent mean \pm SE of triplicate wells and are representative of two independent experiments.

termediate affinity IL-2R $\beta \gamma$ and the high affinity IL- $2 \mathrm{R} \alpha \beta \gamma$ (18-20). We therefore compared the effects of monocyte-derived IL-15 versus T cell-derived IL- 2 on MIP-1 $\alpha$ production in the CD56 $6^{\text {bright }} \mathrm{NK}$ cell subset. Each cytokine induced MIP-1 $\alpha$ production in a dose dependent fashion (Fig. 5 A). However, IL-2 was active at 10 -fold lower concentrations than IL-15, presumably because IL-2R $\alpha \beta \gamma$ can selectively bind IL- 2 with high affinity. This was confirmed by activating CD56 $6^{\text {bright }} \mathrm{NK}$ cells with $1 \mathrm{ng} / \mathrm{ml}$ IL-2 in the absence or presence of anti-CD25 $\mathrm{mAb}$, which selectively blocks IL-2 binding to the high affinity IL-2R $\alpha \beta \gamma$ (18). CD56 $6^{\text {bright }} \mathrm{NK}$ cell MIP- $1 \alpha$ production at $1 \mathrm{ng} /$ $\mathrm{ml}$ IL-2 was completely abrogated in the presence of antiCD25 mAb (Fig. 5 B). At higher concentrations of IL-2 and IL-15 that activate the intermediate affinity IL-2R $\beta \gamma$ (i.e., 100 $\mathrm{ng} / \mathrm{ml}$ ), each cytokine induced equivalent amounts of MIP-1 $\alpha$ production (Fig. $5 \mathrm{~A}$ ).

\section{Discussion}

After infection with obligate intracellular pathogens and gram negative organisms, monocytes are known to elaborate a num- ber of cytokines, such as IL-12, IL-1 $\beta$, TNF- $\alpha$, and IL-15, each of which can activate NK cells $(15,17,21)$. NK cells, in turn, produce IFN- $\gamma$ which is critical for elimination of these pathogens by monocytes (2). In this study, we examine NK cells for the production of additional factors which may be involved in this positive feedback loop between innate immune effector cells. We provide the first evidence that NK cells produce the chemokine MIP- $1 \alpha$, and do so in response to monocyte/macrophage-derived factors. Unfractionated MIP-1, containing both the $\alpha$ and $\beta$ fractions, has previously been shown to potentiate IFN- $\gamma$-inducible secretion of inflammatory cytokines by monocytes, such as IL-1 $\beta$ and TNF- $\alpha$ (5). Recently, MIP- $1 \alpha$ has been shown to contribute to the suppression of the level of HIV replication in vitro (6). Thus, NK-produced MIP-1 $\alpha$ may assist in the control of both obligate intracellular and HIV infections in monocytes, via a paracrine positive feedback loop. Likewise, NK cell production of MIP- $1 \alpha$ may also contribute to septic shock, as has been proposed for IFN- $\gamma$ and TNF- $\alpha(3,4)$.

Significant MIP- $1 \alpha$ production by NK cells requires specific costimulation with IL-12 and IL-15, while combinations of IL-12 and IL-10, IL-1 $\beta$, or TNF- $\alpha$ were not effective. This is in 
distinct contrast to NK cell IFN- $\gamma$ production which can be induced by IL-12 in combination with any of these other monocyte-derived cytokines $(15,21,22)$. NK cell MIP- $1 \alpha$ production therefore appears to define the first unique role for monocytederived IL-15 as a critical cofactor in NK activation. This may have relevance in vivo, as we have recently demonstrated that LPS-activated human monocytes secrete IL-15 protein over a similar time course as IL-12 (17). We also show TGF- $\beta$ to be a potent inhibitor of NK cell MIP- $1 \alpha$ production induced by costimulation with IL-12 and IL-15. This may also have relevance in vivo, as $\mathrm{HIV}^{+}$individuals have an increased plasma concentration of active TGF- $\beta$ (23). IL-2 is a T cell-derived cytokine that is produced after antigen activation (24). Its ability to induce modest MIP- $1 \alpha$ production via the high affinity IL$2 \mathrm{R} \alpha \beta \gamma$ in $\mathrm{CD} 56^{\text {bright }} \mathrm{NK}$ cells suggests a potential role for MIP$1 \alpha$ during the antigen specific immune response.

NK cells upregulate a high affinity MIP- $1 \alpha$ receptor in response to costimulation by IL-12 and IL-15, as demonstrated by Northern blot and protein binding analyses. This observation supports the work of Maghazachi et al, showing that MIP$1 \alpha$ is a chemoattractant for NK cells (25). Hence one role of NK cell MIP-1 $\alpha$ receptor expression may be to direct NK cells toward other important sources of MIP- $1 \alpha$ production, such as LPS-activated monocytes (26). This physical migration would assist in establishing the effective paracrine positive feedback loops required to control infection $(1,2,15,21)$. Our data suggest that MIP-1 $\alpha$ receptor expression may also serve to enhance NK cell killing of pathogens.

In summary, we provide the first evidence that human NK cells produce the chemokine MIP- $1 \alpha$ in response to costimulation by a specific combination of monocyte-derived cytokines. NK cell MIP-1 $\alpha$ and MIP- $1 \alpha$ receptor expression are likely to participate in the innate immune response after monocyte activation, via paracrine and autocrine positive feedback loops. The contribution of NK cell MIP-1 $\alpha$ to control of infection, inflammation and septic shock will likely be elucidated in studies that involve mice lacking the MIP- $1 \alpha$ gene product (27). The ability to selectively expand the NK cell population in $\mathrm{HIV}+$ patients (as a potential source of MIP-1 $\alpha$ ) without increasing HIV mRNA load (28) may provide an additional therapeutic modality to aid in slowing the clinical progression of AIDS.

\section{Acknowledgments}

We would like to thank Mr. Matthew J. Lindemann for technical assistance, Mr. David Sheedy for cell sorting, Mr. Patrick Elder for the Scatchard analyses, and Ms. Wendy Ralph for preparation of the manuscript. We thank Dr. H. Klingemann for the NK-92 cell line, Dr. D. R. Forsdyke for the GOS19.1 cDNA probe, and Dr. T. Schall for the C-C CKR-1 cDNA probe.

This work was supported by CA68456-01 and by the Coleman Leukemia Research Fund.

\section{References}

1. Scott, P., and G. Trinchieri. 1995. The role of natural killer cells in hostparasite interactions. Curr. Opin. Immunol. 7:34-40.

2. Bancroft, G. J. 1993. The role of natural killer cells in innate resistance to infection. Curr. Opin. Immunol. 5:503-510.

3. Heremans, H., C. Dillen, J. van Damme, and A. Billiau. 1994. Essential role for natural killer cells in the lethal lipopolysaccaride-induced Shwartzmanlike reaction in mice. Eur. J. Immunol. 24:1155-1160.

4. Wysocka, M., M. Kubin, L. Viera, L. Ozmen, G. Garotta, P. Scott, and G. Trinchieri. 1995. Interleukin-12 is required for interferon- $\gamma$ production and le- thality in lipopolysaccharide-induced shock in mice. Eur. J. Immunol. 25:672676.

5. Fahey, T.J., III, K.J. Tracy, P. Tekamp-Olson, L.S. Cousins, W.G. Jones, G.T. Shires, A. Cream, and B. Sherry. 1992. Macrophage inflammatory protein 1 modulates macrophage function. J. Immunol. 148:2764-2769.

6. Cocchi, F., A.L. DeVico, A. Garzino-Demo, S.K. Arya, R.C. Gallo, and P. Lusso. 1995. Identification of RANTES, MIP-1 $\alpha$, and MIP-1 $\beta$ as the major HIV-suppressive factors produced by $\mathrm{CD}^{+} \mathrm{T}$ cells. Science (Wash. DC). 270: 1811-1815.

7. Matos, M.E., G.S. Schnier, M.S. Beecher, L.K. Ashman, D.E. Williams, and M.A. Caligiuri. 1993. Expression of a functional $c$-kit receptor on a subset of natural killer cells. J. Exp. Med. 178:1079-1084.

8. Gong, J., G. Maki, and H.-G. Klingemann. 1994. Characterization of a human cell line (NK-92) with phenotypical and functional characteristics of activated natural killer cells. Leukemia. 8:652-658.

9. Baiocchi, R.A., M.E. Ross, J.C. Tan, C. Chou, L. Sullivan, S. Haldar, M. Monne, M.V. Seiden, S.K. Narula, J. Sklar, C.M. Croce, and M.A. Caligiuri. 1995. Lymphomagenesis in the SCID-hu mouse involves abundant production of human interleukin-10. Blood. 85:1063-1074.

10. Blum, S., R.E. Forsdyke, and D.R. Forsdyke. 1990. Three human homologs of a murine gene encoding an inhibitor of stem cell proliferation. DNA Cell Biol. 9:589-602.

11. Neote, K., D. DiGregorio, J.Y. Mak, R. Horuk, and T.J. Schall. 1993. Molecular cloning, functional expression, and signaling characteristics of a C-C chemokine receptor. Cell. 72:415-425.

12. Avalos, B.R., K.J. Bartynski, P.J. Elder, M.S. Kotur, W.G. Burton, and N.M. Wilkie. 1994. The active monomeric form of macrophage inflammatory protein-1 $\alpha$ interacts with high- and low-affinity classes of receptors on human hematopoietic cells. Blood. 84:1790-1801.

13. Scatchard, G. 1949. The attractions of proteins for small molecules and ions. Ann. NY Acad. Sci. 51:660-672.

14. Munson, P.J., and D. Rodbard. 1980. Ligand: A versatile computerized approach for characterization of ligand-binding systems. Anal. Biochem. 107: 220-239.

15. Carson, W.C., J.G. Giri, M.J. Lindemann, M.L. Linett, M. Ahdieh, R. Paxon, D. Anderson, J. Eisenmann, K. Grabstein, and M.A. Caligiuri. 1994. Interleukin (IL) 15 is a novel cytokine that activates human natural killer cells via a component of the IL-2 receptor. J. Exp. Med. 180:1395-1403.

16. Siderovski, D.P., R.E. Forsdyke, and D.R. Forsdyke. 1990. A set of human putative lymphocyte $\mathrm{G}_{0} / \mathrm{G}_{1}$ switch genes includes genes homologous to rodent cytokine and zinc finger protein-encoding genes. DNA Cell Biol. 9:579587.

17. Carson, W.E., M.E. Ross, R.A. Baiocchi, M.J. Marien, N. Boiani, K. Grabstein, and M.A. Caligiuri. 1995. Endogenous production of interleukin 15 by activated human monocytes is critical for optimal production of interferon- $\gamma$ by natural killer cells. J. Clin. Invest. 96:2578-2582.

18. Caligiuri, M.A., A. Zmuidzinas, T.J. Manley, H. Levine, K. Smith, and J. Ritz. 1990. Functional consequences of interleukin-2 receptor expression on resting human lymphocytes. J. Exp. Med. 171:1509-1526.

19. Voss, S.D., P.M. Sondel, and R.J. Robb. 1992. Characterization of the interleukin 2 receptors (IL-2R) expressed on human natural killer cells activated in vivo by IL-2: association of the p64 IL-2R $\gamma$ chain with the IL-2R $\beta$ chain in functional intermediate-affinity IL-2R. J. Exp. Med. 176:531-541.

20. Nakarai, T., M.J. Robertson, M. Streuli, Z. Wu, T.L. Ciardelli, K.A. Smith, and J. Ritz. 1994. Interleukin 2 receptor $\gamma$ chain expression on resting and activated lymphoid cells. J. Exp. Med. 180:241-251.

21. Tripp, C.S., S.F. Wolf, and E.R. Unanue. 1993. Interleukin 12 and tumor necrosis factor $\alpha$ are costimulators of interferon $\gamma$ production by natural killer cells in severe combined immunodeficiency mice with listeriosis, and interleukin 10 is a physiological antagonist. Proc. Natl. Acad. Sci. USA. 90:3725-3729.

22. Carson, W.E., M.J. Lindemann, R.A. Baiocchi, M.J. Linett, J.C. Tan, C.-C. Chou, S. Narula, and M.A. Caligiuri. 1995. The functional characterization of interleukin-10 receptor on human natural killer cells. Blood. 85:3577-3585.

23. Allen, J.B., H.L. Wong, PM. Guyre, G.L. Simon, and S.M. Wahl. 1991. Association of circulating receptor FcyIII-positive monocytes in AIDS patients with elevated levels of transforming growth factor- $\beta$. J. Clin. Invest. 87:1773-1779.

24. Smith, K.A. 1988. Interleukin-2: inception, impact, and implications. Science (Wash. DC). 240:1169-1176.

25. Maghazachi, A.A., A. Al-Aoukaty, and T.J. Schall. 1994. C-C chemokines induce the chemotaxis of NK and IL-2-activated NK cells. J. Immunol. 153:4969-4977.

26. Wolpe, S.D., G. Davatelis, B. Sherry, B. Beutler, D.G. Hesse, H.T. Nguyen, L.L. Moldawer, C.F. Nathan, S.F. Lowry, and A. Cerami. 1988. Macrophages secrete a novel heparin binding protein with inflammatory and neutrophil chemokinetic properties. J. Exp. Med. 167:570-581.

27. Cook, D.N., M.A. Beck, T.M. Coffman, S.L. Kirby, J.F. Sheridan, I.B. Pragnell, and O. Smithies. 1995. Requirement of MIP-1 $\alpha$ for an inflammatory response to viral infection. Science (Wash.DC). 269:1583-1585.

28. Bernstein, Z.P., M.M. Porter, M. Gould, B. Lipman, E.M. Bluman, C.C Stewart, R.G. Hewitt, G. Fyfe, B. Poiesz, and M.A. Caligiuri. 1995. Prolonged administration of low-dose interleukin-2 in human immunodeficiency virusassociated malignancy results in selective expansion of innate immune effectors without significant clinical toxicity. Blood. 86:3287-3294. 